\title{
Scrotal Morphometric Properties of Yearling West African Dwarf Goats Fed Cashew Nut Shell Based Diets
}

\author{
Ocheja Josiah Omachi ${ }^{1, ~}{ }^{*}$, Torhemen Micheal $^{3}$, Abalaka Ezra Onuh ${ }^{2}$, Akinleye Sule Bamidele ${ }^{4}$, \\ Shaibu Peace Ojochide ${ }^{2}$, Ali Peter Anyo ${ }^{2}$, Faruna Samuel Sule ${ }^{2}$, Odiba Arome Abdulkadir \\ ${ }^{1}$ Department of Animal Science, Federal University,Kashere,Gombe , Nigeria \\ ${ }^{2}$ Department of Animal Production,Kogi State University, Anyigba, Nigeria \\ ${ }^{3}$ Department of Animal Husbandry,AkperanOrshi College of Agriculture ,Yandev, Gboko , Nigeria \\ ${ }^{4}$ Department of Animal Science, University of Ibadan, Ibadan, Nigeria \\ ${ }^{5}$ Department of Animal Science,Ahmadu Bello University, Zaria, Nigeria
}

Email address:

josiahocheja@yahoo.co.uk (O. J. Omachi)

${ }^{*}$ Corresponding author

\section{To cite this article:}

Ocheja Josiah Omachi, Torhemen Micheal, Abalaka Ezra Onuh, Akinleye Sule Bamidele, Shaibu Peace Ojochide, Alih Peter Anyo, Odiba Arome Abdulkadir. Scrotal Morphometric Properties of Yearling West African Dwarf Goats Fed Cashew Nut Shell Based Diets. Animal and Veterinary Sciences. Special Issue: Promoting Animal and Veterinary Science Research. Vol. 8, No. 4, 2020, pp. 80-83.

doi: $10.11648 /$ j.avs.20200804.13

Received: June 4, 2020; Accepted: July 3, 2020; Published: August 5, 2020

\begin{abstract}
Sixteen (16) yearling male West African dwarf goats were allotted into four (4) treatment of four goats each. The goats were fed diets containing varying levels of cashew nutshell $0 \%\left(\mathrm{~T}_{1 \text {, control }}\right), 10 \%\left(\mathrm{~T}_{2}\right), 15 \%\left(\mathrm{~T}_{3}\right)$ and $20 \%\left(\mathrm{~T}_{4}\right)$ at $150 \mathrm{~g}$ per goat per day andGuinea grass at $500 \mathrm{~g}$ per goat per day for sixty three (63) days, to determine the effects of cashew nut shell based diets on the scrotal morphometric characteristics of the Goats. The scrotal morphometric measurements were taken before the commencement of the experiment and again on the last day of the experiment. The daily forage intake, and daily dry matter intake values were both significantly different, the daily supplement intake values were not significantly different. The values for final scrotal length, and circumference, were not significant. The final scrotal circumference (14.40-16-50 $\mathrm{cm})$ showed significant $(\mathrm{p}<0.05)$ difference, the values for increase in scrotal length were slightly significant $(\mathrm{p}<0.05)$ and did not follow any definite trend, values for scrotal weight ranged from 48.90-66.80g and showed significant $(p<0.05)$ differences with $\mathrm{T}_{2}$. having the highest the right and left testicular weights were both significantly $(\mathrm{P} .<0.05)$ different. It was there for concluded that the diets containing cashew nut shell had better scrotal morphometric values the control, with $\mathrm{T}_{2}(10 \%$ cashew nut shell) being the best. The inclusion of cashew nut shell in diets for Goats at $10 \%$ level was therefore recommended. Further research using other breeds and classes of goats as well as other species of ruminants werealso recommended.
\end{abstract}

Keywords: Scrotal, Morphometry, West African Dwarf Goats, Cashew Nutshell, Diets

\section{Introduction}

Nutrition is and remainsone of the most important factors that determine the success, development and expansion of thelivestock sector in the tropics. The inability of ruminant livestock farmers to feed their animals with high quality forage andconcentrate feedsall year round remains the most wide spread technical constraint facing ruminant productivity in the developing nations [1]. Contemporary ruminant feeding in a developing country like Nigeria is partly geared towards searching for inexpensive readily available feed resources, which can partially or wholly serve as substitute for the scarce expensive feed stuffs and inadequate forage [2].

Since grasses and legume which constitute a major proportion of forage which are the basal feed for ruminants, are usually in short supply during the long dry season, there is need therefore to feed ruminants with concentrate supplement diets, more over nutrition has effects on the reproductive ability of animals, scrotal morphometric 
measurementsplay an important role in this regard. Morphometry has been described as the measurement of external forms especially of living systemsor their parts [3, 4], it is a concept that encompasses size, and shape. morphometric analyses are commonly performed on organism and are useful in analyzing developmental changes in form, covariance between ecology factors and shape as well as estimating quantitative genetic parameters of shape. Several studies have shown the relationship between nutrition and reproduction., for instance Shoenianreported that scrotal circumference was an important indicator when observing animals and an essential part of breeding soundness evaluation, he posited that scrotal circumference measurement gives a good indication of a rams breeding ability.[5] Ashwoodopined that scrotal circumference is the most accurate indicator of testis size and its measurement directly related to the massof sperm producing tissue, sperm cell normality etc [6]. Testicular and epididymal morphological characteristics may be a useful selection criterion for improvement of reproductive ability. Variation in rate of sperm production with large difference in testicular weight resulted in a wide difference in total sperm production among Rams. A relationship exists between semen quality and testicular dimension indicating that improvement in one would lead to improvement in theother. The use of males with greater testicular development and consequently with higher fecundity is important to ensure good reproduction efficiency of the flock [7]. Consequently this study was therefore designed to study the effects of cashew nut shell baseddietson the Scrotal Morphometry of West African Dwarf Goats.

\section{Materials and Methods}

\subsection{Location of the Experiment}

The experiment was conducted at the Sheep and Goat unit of Kogi State University, Livestock Teaching and Research farm, Anyigba. Anyigba is located in the derived Guinea Savannah zone of Nigeria on latitude $7^{\circ} 15^{\prime}$ and $7^{\circ} 29^{\prime} \mathrm{N}$ of the equator and longitudes $7^{\circ} 11^{\prime}$ and $7^{\circ} 32^{\prime} \mathrm{E}$ of the Greenwich meridian. The zone lies in the warm humid climate of the tropics with clearly marked wet and dry season in April to October and November to march respectively with annual rainfall ranging from 1400$1500 \mathrm{~mm}$ and an ambient temperature of about $25^{\circ} \mathrm{C}$ with the highest in March and April [8].

\subsection{Experimental Animals, Management, Feed Preparation and Experimental Procedure}

A total of 16 yearling male West African dwarf goats were sourced from Anyigba and its environs. The animals were housed individually and treated with Ivomec, for endo and ecto parasite control at $0.3 \mathrm{ml}$ each and oxytetracycline, hydrochloride and procaine penicillin at $2.0 \mathrm{ml}$ each to take care of scouring and nasal discharge and to provide a common health status. The Guinea grass (Panicum maximum) used for thisexperiment were collected from within Kogi State University Campus, Anyigba. and wilted for 24 hours to reduce the moisture content before feeding. The cashew nutshell was collected from kogi state university cashew processing plant and was pounded and mixed thoroughly with other feed ingredients such as Maize offal (MO), Bambara nut offal (BO), Fish offal (FO), Rice offal (RO), Wood ash (WA), Bone meal, Table salt and ground to desired texture.

The goats were allotted in a Completely Randomized Design (CRD) into four (4) treatments. Each treatment had four (4) goats. each goat was fed $150 \mathrm{~g}$ of the supplement diet per day. and Guinea grass at $500 \mathrm{~g}$ per Goat per dayof which the Guinea grasswas fed first, then the supplement one hour later, the Goats were served water ad-libitum. Feed offered to the goats was weighed daily and the left over was also weighed and subtracted from the quantity of feed served to determine the feed intake of the animals.. The experiment lasted for sixty three (63) days after an adjustment period of seven (7) days.

Table 1. Composition of Experimental Diets (\% DM).

\begin{tabular}{lllll}
\hline \multirow{2}{*}{ Ingredients } & \multicolumn{4}{l}{ Composition/Treatments } \\
\cline { 2 - 5 } & $\mathbf{T}_{\mathbf{1}}$ & $\mathbf{T}_{\mathbf{2}}$ & $\mathbf{T}_{\mathbf{3}}$ & $\mathbf{T}_{\mathbf{4}}$ \\
\hline Cashew nut shell & 0.00 & 10.00 & 15.00 & 20.00 \\
Bambara Nut Offal & 20.00 & 20.00 & 20.00 & 20.00 \\
Cereal Spent Grains & 28.00 & 28.00 & 28.00 & 28.00 \\
Maize Offal & 30.00 & 23.00 & 21.00 & 20.00 \\
Rice offal & 18.50 & 15.50 & 12.50 & 8.50 \\
Wood ash & 0.50 & 0.50 & 0.50 & 0.50 \\
Table salt & 1.50 & 1.50 & 1.50 & 1.50 \\
Mineral Premix & 0.50 & 0.50 & 0.50 & 0.50 \\
Calculated nutrient content (\% DM) & & & \\
Nutrients & & & & \\
Crude protein & 17.70 & 17.15 & 17.09 & 17.01 \\
Crude fibre & 16.18 & 16.52 & 16.56 & 16.63 \\
ME (Kcal/kgDM) & 2950 & 2980 & 2995 & 3015 \\
\hline
\end{tabular}

\subsection{Data Collection}

Data on feed consumption,(daily supplement intake, daily forage intake and total dry matter intake) and Scrotal morphometric measurements (initial scrotal length, final scrotal length, increase in scrotal length, initial scrotal circumference, final scrotal circumference, increase in scrotal circumference, scrotal weight, right testicular weight and left testicular weight) were determined.

\subsection{Scrotal Morphometric Measurements}

The scrotal morphometric measurements were taken at the beginning of the experiment and on weekly basis thereafter up to the last day of the experiment. The scrotal circumference was taken by placing a measuring tape around the scrotal sac, the scrotal length was taken by placing a measuring tape verticallyon the scrotal sac, and reading off the values, measurements were in centimeters $(\mathrm{cm})$. The scrotal weight was determined by cutting off the scrotum of each slaughtered goat andweighing, the scrotal sac was thereafter sectioned and each testicle removed and weighed to obtain the weights of the right and left testicles 


\subsection{Chemical Analysis}

Samples of Guinea grass (Panicum maxiumum) and the supplement diets were analyzed for their proximate composition using standard procedure [9].

\subsection{Experimental Design and Statistical Analysis}

The experimental design was a completely randomized design (CRD). Data were subjected to a one-way analysis of variance (ANOVA); treatment means that were significantly different were separated using least significant difference (LSD) with the aid of SPSS version 16. [10]

\section{Results and Discussion}

\subsection{Proximate Composition of Concentrate Diets and Guinea Grass}

The proximate composition of the concentrate diets and Guinea Grass is presented in Table 2.

The concentrate diets were iso-nitrogenous with crude protein values ranging from $17.17-17.69 \%$, these values fell within the range of $12-18 \%$ recommended for growing ruminants in the tropics $[11,12]$. The dry matter content of the concentrate diets ranged from $90-18-90.97 \%$, they were quite higher than that of Guinea Grass which was $64.0 \%$, in general, concentrates will usually have higher dry matter content than Grasses and legumes The ether extracts values of $10.84-14.99 \%\left(\mathrm{~T}_{2}-\mathrm{T}_{4}\right)$ were above recommended values forgoats, the values however suggests high carotene and fat soluble vitamins content [13].

Table 2. Proximate Composition of Concentrate Diets and Guinea Grass $(\% D M)$.

\begin{tabular}{llllll}
\hline \multirow{2}{*}{ Nutrients } & \multicolumn{2}{l}{ Treatment } & \multicolumn{2}{c}{ Guinea } \\
\cline { 2 - 5 } & $\mathbf{T}_{\mathbf{1}}$ & $\mathbf{T}_{\mathbf{2}}$ & $\mathbf{T}_{\mathbf{3}}$ & $\mathbf{T}_{\mathbf{4}}$ & Grass \\
\hline Crude Protein & 17.69 & 17.56 & 17.17 & 17.32 & 10.48 \\
Crude Fibre & 16.89 & 17.09 & 18.03 & 18.80 & 24.53 \\
Nitrogen Free Extracts & 57.51 & 51.23 & 49.47 & 45.88 & 51.64 \\
Ether Extracts & 4.48 & 10.84 & 12.04 & 14.99 & 1.90 \\
Ash & 3.43 & 3.28 & 3.29 & 3.10 & 11.45 \\
Dry Matter & 90.66 & 90.59 & 90.97 & 90.18 & 64.98 \\
\hline
\end{tabular}

\subsection{Feed Intake of Experimental Goats}

The feed intake of the experimental Goats is presented in Table 3.

Daily concentrateintake values were not significantly $(\mathrm{P}>$ 0.05 ) different, with values ranging from $81.10-89.70 \mathrm{~g}$. the dailyforage intake showed significance $(\mathrm{p}<0.05)$ with $\mathrm{T}_{4}$ having the highest $(367.80 \mathrm{~g})$. This was in line with the report of Tolera et al., who stated that supplementation of forages with concentrate feed stuff is a necessity in improving goats' productivity. [14] The values obtained for total drymatter intake (423.40-451.70 g) were higher than 235.91-388.32g obtained by Ifut et al., and also higher than $216.75-261.61 \mathrm{~g}$ reported by Ocheja et al. $[15,16]$ This difference could be due to the supplements fed to the goats as well as the breeds and class of goats used for the feeding trials.
Table 3. Fed Intake of Experimental Goats.

\begin{tabular}{llllll}
\hline \multirow{2}{*}{ Parameters } & \multicolumn{3}{l}{ Treatments } & \multicolumn{2}{l}{ SEM } \\
\cline { 2 - 5 } & $\mathbf{T}_{\mathbf{1}}$ & $\mathbf{T}_{\mathbf{2}}$ & $\mathbf{T}_{\mathbf{3}}$ & $\mathbf{T}_{\mathbf{4}}$ & \\
\hline Number of goats & 4 & 4 & 4 & 4 & - \\
Duration (days) & 63 & 63 & 63 & 63 & - \\
Daily Concentrateintake $(\mathrm{g})$ & 89.70 & 86.70 & 81.10 & 84.70 & 2.70 \\
Daily Forage intake $(\mathrm{g})$ & $348.20^{\mathrm{b}}$ & $336.70^{\mathrm{c}}$ & $362.06^{\mathrm{a}}$ & $367.80^{\mathrm{a}}$ & 5.68 \\
Total daily Dry Matter intake $(\mathrm{g})$ & $437.90^{\mathrm{b}}$ & $423.40^{\mathrm{c}}$ & $443.16^{\mathrm{a}}$ & $451.70^{\mathrm{a}}$ & 7.55 \\
\hline
\end{tabular}

$\mathrm{a}, \mathrm{b}, \mathrm{c}=$ Treatment means on the same row with different superscripts differ significantly $(\mathrm{p}<0.05)$.

$\mathrm{SEM}=$ Standard Error of Means.

\subsection{Scrotal Morphometric Characteristics}

The effect of cashew nutshell based dietson the Scrotal morphometry of the experimental Goats is presented in Table 4. The values for the final scrotal circumference (16.55$18.45 \mathrm{~cm}$.) were significant $(\mathrm{p}>0.05)$ they were lower than $25.30-27.63 \mathrm{~cm}$ reported by Pant et al [17]. The values for final scrotal length which ranged from $9.13-11.70 \mathrm{~cm}$ were significantly $(\mathrm{p}>0.05)$ different, the values were lower than 17.00-18.61 cm obtained by Campos et al [18], the differences in the final scrotal circumference and finalscrotal length may be due tothe breeds and age of the animals used for the experiment. The final scrotal circumference of $16.55-17.83 \mathrm{~cm}$ obtained in this study was lower than $26.97-30.45 \mathrm{~cm}$ reported by Santos and Simplicio [19]. This discrepancy could be due to the experimental feeds as well as ageand breeds of the goats used, the increase in scrotal length were slightly significant $(\mathrm{P}>0.05)$. The scrotal weight ranged from $48.90-66.80 \mathrm{~g}$ and differed significantly $(\mathrm{P}>0.05)$ with $\mathrm{T}_{2}(10 \%$ cashew nut shell) having the highest, these values were lower than 50 85greported for growingWest African Dwarf Goats fed graded levels of steam-treated cashew nut shell by Ocheja et al.[20] The right testicular weight ranged from $21.60-32.50 \mathrm{~g}$ while the left testicular weight had a range of $21.75-30.40 \mathrm{~g}$, the values for both parameters did not follow any definite trend, and were both significantly $\mathrm{P}<0.05$ ). different. Nasir et al reported a range of 36.0-64.10g for the right testicular weight and $35.10-58.40 \mathrm{~g}$ for the left testicular weight for red Sokoto bucks fed cotton seed cake [21] The observed discrepancies could be attributable to differences in the breeds of Goats used for the study as well as differences in diets fed.

Table 4. Scrotal Morphometry of Experimental Goats.

\begin{tabular}{llllll}
\hline \multirow{2}{*}{ Parameters } & \multicolumn{3}{l}{ Treatments } & \multirow{2}{*}{ SEM } \\
\cline { 2 - 5 } & $\mathbf{T}_{1}$ & $\mathbf{T}_{2}$ & $\mathbf{T}_{3}$ & $\mathbf{T}_{4}$ & \\
\hline Final Scrotal Circumference (cm) & $17.83^{\mathrm{a}}$ & $16.55^{\mathrm{b}}$ & $18.45^{\mathrm{a}}$ & $16.75^{\mathrm{b}}$ & 0.75 \\
Increase in Scrotal & $1.65^{\mathrm{a}}$ & $1.90^{\mathrm{a}}$ & $0.60^{\mathrm{b}}$ & $1.70^{\mathrm{a}}$ & 0.63 \\
Circumference (cm) & $10.80^{\mathrm{a}}$ & $9.13^{\mathrm{b}}$ & $11.70^{\mathrm{a}}$ & $11.00^{\mathrm{a}}$ & 1.22 \\
Final Scrotal length (cm) & $1.50^{\mathrm{b}}$ & $2.70^{\mathrm{a}}$ & $0.90^{\mathrm{c}}$ & $1.50^{\mathrm{b}}$ & 0.28 \\
Increase in Scrotal Length (cm & $50.90^{\mathrm{b}}$ & $66.80^{\mathrm{a}}$ & $52.60^{\mathrm{b}}$ & $48.90^{\mathrm{b}}$ & 5.20 \\
Scrotal Weight (g) & $22.50^{\mathrm{b}}$ & $32.50^{\mathrm{a}}$ & $23.60^{\mathrm{b}}$ & $21.60^{\mathrm{b}}$ & 2.68 \\
Right Testicular Weight (g) & $21.75^{\mathrm{b}}$ & $30.40^{\mathrm{a}}$ & $22.80^{\mathrm{b}}$ & $20.90^{\mathrm{b}}$ & 2.56 \\
Left Testicular Weight (g) & & & & & \\
\hline
\end{tabular}

$a, b, c$ Treatment means on the same row with different superscript differs significantly $(\mathrm{p}>0.05)$.

$\mathrm{SEM}=$ Standard Error of Means. 


\section{Conclusion and Recommendations}

\subsection{Conclusion}

The Guinea grassandthe concentrate diets had adequate array of nutrients for Goats. $\mathrm{T}_{4}(20 \%$ cashew nutshell) had the highest feed intake records. Diets containing cashew nut shell $\left(\mathrm{T}_{2}-\right.$ $\mathrm{T}_{4}$ ) had better scrotal morphometric records of which $\mathrm{T}_{2}$ ( $10 \%$ cashew nutshell) had the best values.

\subsection{Recommendations}

Further research should be carried out on other grass species. So as to ascertain their nutritivevalue as well as their effects on the ScrotalMorphometry of goats.

Further research should also be carried outusing other classes and breeds of goats as well as other species of ruminants.

Ten (10) percent cashew nut shell can be included in goats diets for the improvement of scrotal morphometry and hence reproductive ability.

\section{References}

[1] Bawala, T. O and Akinsoyinu A. O (2002) Nutritional evaluation of browse Gliricidiasepium and Ficus thoningii foliage in goat diet. Energy utilization and requirement. Proceeding of $37^{\text {th }}$ Conference of NSAP, University of Agriculture, Abeokuta, Nigeria Pp 174-176.

[2] Okoruwa, M. I and Adewumi, M. K (2010) Effect of replacing Panicum maximum with dried pineapplepulp on nutrient digestibility and nitrogen balance of west African dwarf Sheep [Nigerian Journal of Animal Science 32: 108-115.

[3] Marriam Webster (2014). Definition of Assay. Medicinnet. Com. ministry of Agriculture (MOA) (1985). Project preparation report- Sheep production project. Annexes: 1-6 Australian Agricultural Consulting and Management Company Pty. Ltd. March 1985.

[4] Wikipedia (2014). Morphomery. Available at: www.Wikipidia.com.

[5] Schoenian, S. (2012). Sheep 201. Beginners guide to raising sheep. Available in: http://www.sheep101.info/201.

[6] Ashwood, A. (2009). Bull Reproduction Soundness: Brahman News. 164

[7] Nse-Abasi N. E (2015) Testicular and Epididymal Morphometric Characteristics: Viable Indicators of Reproductive. Ability of Farm Animals. American Journal of Biomedical Science. 1 (439-44).

[8] Ifatimehin O. O., Musa S. D and Adeyemi J. O. (2009). An Analysis of the Changing land use, its impacts on the environment of Anyigba Town, Nigerin. Journal of Sustainable Development in Africa 10 (4): 22-29.

[9] AOAC, (1995). Official Methods of Analysis $17^{\text {th }}$ Ed. Association of Analyticalchemists Washington, D.
[10] SPSS (2006): Statistical Package for Social Sciences 16.0 Version. SPSS Inc.

[11] National Research Council (1996). Nutrient Requirements of of Beef Cattle, $7^{\text {th }}$ editionRevised Edition, National Academy Press, Washington D C.

[12] Lakpini C. A. M, Adamu A. M, Ehoche O. W and Gefu J. O (2002). Manual for Small Ruminant Production in Nigeria. Compilation for a Training Workshop on Small Ruminant Production held at the National Animal Production Research Institute, Zaria, Nigeria. 13th-1 $8^{\text {th }}$ January 2002 pp 40-48.

[13] Ambarasu C, Dutta, N, Sharma K, and Rawat M (2004) Response of Goats to partialReplacement of Dietary Protein by a Leaf Mixture Containing Leuceana leucocephala Morus alba and Tectona grandis, Small Ruminant Research 51: 4556.

[14] Tolera, A. Merkel, R. C Goestch A. L., Sahhe T. and Negesse. T. (2000). Nutritional Constraints and Future Prospects for Goat Production in East Africa. In: Merkel, G. Abebe, and A. L. Geostch (Eds). The Opportunities and Challenges of Enhancing Goat Production in East Africa Proc. of a Conference held at Debub University, Awassa, Ethopia, November $10^{\text {th }}-12^{\text {th }}, 2000$. Pp 43-57.

[15] Ifut O. Y, Inyang U A, Udusi I S, and Adeyemi Y. O (2011) Carcass Yield of West African Dwarf Goats fed Forages and brewers Spent Grains, Nigerian Journal of Agriculture, Food and Environment 7 (2): 17-19.

[16] Ocheja J. O, Peter O. P, Oyibo A and Netala J (2016) Effects of Diets containing varying Levels of Cashew Nut Shell on Scrotal Morphomrtric Characteristics of Growing West African Dwarf Goats. Int. Journal of Agriculture and Veterinary Science 2 (3): 101.

[17] Pant H. C, Sharma R. K, Patal S. H, Shukla H. R, Mittal A. K, Kasiraj R. K, Misra A. K, and Prabhakar J. H (2008) Testicular Development and its relationship to semen production in Murah Buffalo bulls 60 .

[18] Compos A. C. N, Nunes Y. F, Silverfiho A. H. S, and Monteiro A. W. U (2003) Parametros Biometricos dotrato genita masculine de esprino sem raca definida Criodo no semi-arid nordestino durante operiod secoe chuvosoBrazilian J Vet Res Anim. Sci 40 (3): 185-189.

[19] [Santos, D. O Simplicio, A. A., (2000). Parametros escrotostesticularese desemen emcaprino adultos submetidos ainsulacao scrotal pesquisa. Agropecuaria Brasileira, 35, 1835-1841. 106.

[20] Ocheja J. O, Usman G. O, Ahmed S. H, Boyi P. U, Akoh J. O, Adamu A. T and Eboh S (2020) Performance and Feed BioEconomics of Growing West African Dwarf Goats FedDiets Containing Graded Levels of Steam-Treated Cashew Nut Shell. Animal and Veterinary Science (Special Issue: Promoting Animal and Veterinary Science Research) 8 (1): 1418.

[21] Nasir M, Njidda A. A, Duwa H, Chibuogwa C. I (2014). Testicular Morphometry of Red Sokoto Bucks fed cotton seed cake. Scholars Journal of Agric and Veterinary Science 1 (4A): 242-248. 